\title{
Analysis of Students' Error in Understanding the Mathematical Problems
}

\author{
$1^{\text {st }}$ Fridgo Tasman \\ Mathematics and Science Faculty \\ Universitas Negeri Padang \\ Padang, Indonesia \\ fridgo_tasman@fmipa.unp.ac.id
}

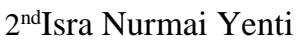 \\ Tarbiyah Faculty \\ IAIN Batusangkar \\ Batusangkar, Indonesia
}

\author{
$3^{\text {rd }}$ Setna Heriyanti \\ Tarbiyah Faculty \\ IAIN Batusangkar \\ Batusangkar, Indonesia
}

\begin{abstract}
Lack of students' mathematical abilities can cause difficulties in solving mathematical problems. The difficulties can be seen from mistakes in mathematical representation on students' answers. This study interested in analyzing error in understanding the mathematical problems and find out the causes of such errors. To answer that, we conducted this research (field research) with 25 students in $\mathrm{VIII}_{4}$ class in MTsN Sunggayang in the form of descriptive research. Students are given a designed test to measure their understanding about the problems. Interviews were conducted to the students who did mistakes in answering mathematical problems. The data were analyzed with data tabulation procedures, analysis of the test results, reducing the data, presenting data and draw conclusions. In general, Most of students understand the given problems but they did not write the information on the problems completely that showed their mathematical communication ability were low.
\end{abstract}

Keywords-Mathematical representation ability, Understanding Mathematical Problems

\section{INTRODUCTION}

Mathematics has vital role in life. Therefore mathematics needs to be taught in formal and non-formal education institutions. At school, mathematics becomes important part in Indonesia. It proved by making mathematics subjects as one of the subject which tested in national exam [8].

The goals of mathematics subject for primary and secondary education in standar isi are to make the students have abilities to: (1) understand mathematical concept, describe the relation of concepts, and apply the concepts or algorithms in solving problems correctly and effectively.(2) use their mathematical reasoning in performing mathematical manipulation, making generalizations, proving evidence, or explaining mathematical ideas. (3) Solve problems including the ability to understand the problem, devising a mathematical model, solving the model, and interpreting the solution. (4) Communicate ideas with symbols, tables, diagrams, or other media to clarify the situation or problem. (5) Respect the use of mathematics in life by curiosity, attention, and interest in studying mathematics and confidence in solving problems [5].
Those capabilities will be meaningful if it supported by good representation ability [3]. Students need this ability as a tool to find and to get solution or way of thinking in communicating mathematical ideas from abstract to concrete in order to make it easier to understand.

Fauzan stated that the importance's of mathematical representation abilities in mathematics are: (1) Mathematical representation necessary for understanding students' mathematical concepts and the relationships between concepts in mathematics. (2) Representations allow students to communicate with a mathematical approach, to argue and to understand themselves and others. (2) Representations allow students to recognize relationships between related concepts and apply the mathematics to a realistic problem [2].

In reality, mathematical representation ability of students' is still low. It proved by research by Hudiono found that only a small proportion of students who were able to answer mathematical problems correctly most of them are weak in mathematical representation [4].

Learning objectives can be determined students' success in solving the given problem. Students are expected to solve problems through the process step by step so it looks groove of thinking.

Students' solution can give information about the success of learning process and students mistakes. The mistakes can be seen from the way the students represent and solve given problems. Students' errors can be seen when they answer and interpret their answer. Interpreting phenomenon with mathematical representation of the can be done with a variety of mathematical form such as visuals (charts, tables, diagrams and drawings); Symbolic (mathematics statement/mathematical notation, numeric or algebraic symbol); and verbal (words or written text).

Based on those forms, there are many students who had mistaken in solving mathematical problems, especially in space geometry with flat sides. So we interested and motivated to analyze students' errors in mathematical representation ability of students in space geometry with flat sides particularly on understanding mathematical problems.

There are many of students' error in solving mathematical problems. It depend on their knowledge. To understand a problem, students need to understand the information or the question on that problem. They need to see whether the information on the problems is enough and 
try to express or to write the problem in a more operational in order to make it easier to solve. [9] stated that students' error in understanding mathematical problems consist of three aspects. They are (1) error in understanding problems instruction. (2) error in understanding keyword of the problem and (3) error in classifying relevance data. However in this paper we discuss students' error in determining the information on the problems and error in understanding the problem instruction.

\section{METHODS}

To know and to describe the students' error in understanding the mathematical problems, field research were chosen as the type of research in forms of descriptive research with quantitative and qualitative methods. Descriptive research is research that sought to describe and interpret the objects according to what it is [6]. While Arikunto states that descriptive research is intended to gather information about an existing symptoms, which is the state according to what their symptoms at the time of the study [1]. Subjects of this research were 25 students of VIII4 class in MTsN Sunggayang.

The stages of research can be seen in figure 1 below.



Fig. 1 Research stages

\section{RESULT AND DISCUSSION}

Students can understand the problem if they are able to write what is known and able to understand the instruction to answer the problem correctly. In order to analyze students' error in understanding the mathematical problems, we give them two problems, where in those problems we give two statements. They need to stated whether the statement right or wrong by making a checklist in given column and give their reason on that answers.

The first statement is "A rectangular prism box made of iron containing oil. First, the oil issued 50\% from the box, and then expelled again one-third of the rest. Finally, the oil in the box is about 40 liters. How many liters of oil in the box before it were issued at all? Based on the problem, we can be stated that: the amount of oil released $50 \%+1 / 3$ and the remaining oil after it is issued is 40 liters".

The second statement is "Mr Budi wants to make a cubeshaped chicken coop with frame made of iron. He planned to make the cage length about $40 \mathrm{~cm}$. If Mr Budi has a 30 meter iron material, determine the number of cages that can be made! Information can be understood from the question is the length of the cage $40 \mathrm{~cm}$ and iron materials provided along $30 \mathrm{~m}$ "

From those problems we get table 1 that shows the percentages of students with wrong answer.

Table 1. Percentages of Students with Wrong Answer

\begin{tabular}{|c|c|c|}
\hline Problem & $\begin{array}{c}\text { Number of Students that Making } \\
\text { Error }\end{array}$ & Percentage \\
\hline 1 & 15 & $60 \%$ \\
\hline 2 & 16 & $64 \%$ \\
\hline \multicolumn{2}{|c|}{ Rata-rata } & $\mathbf{6 2 \%}$ \\
\hline
\end{tabular}

Table 1 showed that there are most of students got wrong answers. Here is one example of student's answers of problem no 1 .

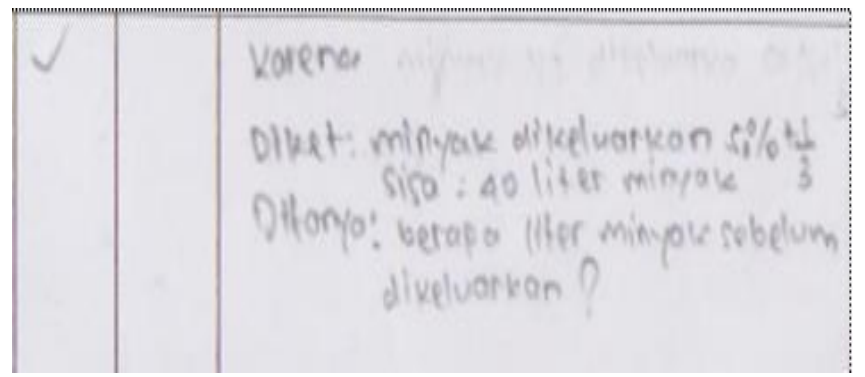

Fig. 2 Student's Answer of Problem 1

Figure 2 shows that the student tick the column right and write his reason in the reason box. He writes all information on the statement of problem 1 . However, that the student did mistake in making mathematical model of situation that means students did mistake on making what is known from the problem. Therefore we conducted interview with him. Here is the transcript of the interviewer (I) with the student (S).

I : Please read that problem (Problem 1)!

S: (Reading problem 1)

I : Do you understand that problem?

S: Yes, I am

I : What information that you get from that problem?

S: First, the oil issued $50 \%$ and expelled again one-third of the rest. Finally the oil in the box is 40 liters. 
I : What that means?

S: The oil issued $50 \%$ and expelled again one-third of the rest

I : Is that the expression $50 \%+1 / 3$ correct for the amount of oil issued from its box?

S: Yes, that's correct.

I : Do you have another mathematical expression?

S: No, I don't.

That transcript tells us that the student is able to retell and to rewrite the information. However, he tells and writes completely same with the information on the problem. He unable to write the correct expression based on the situation that shown the ability to express the situation on mathematical expression is still low.

Another student answer on that problem with different reason as shown in figure 3 below.

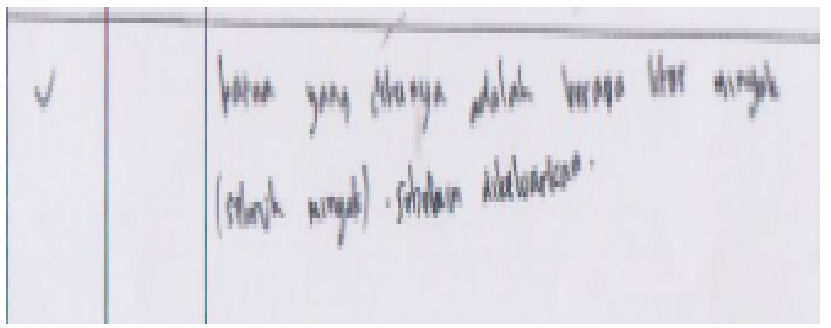

Fig. 3 Another Answer of Problem Number 1

Figure 3 shows that the student tick the column right and write his reason in the reason box. He writes "because the problem asked the amount of the oil before the oil expelled". This student did not make the reason based on the information on the problem. Therefore we conducted interview with him. Here is the transcript of the interviewer (I) with the student (S).

I : Please read that problem (Problem 1)!

S: (Reading problem 1)

I : Do you understand that problem?

S: Yes, I am

I : What information that you get from that problem?

$\mathrm{S}$ : A rectangular prism box made from iron containing oil. First, the oil issued 50\% from the box, and then expelled again one-third of the rest. The problem asked the amount of oil in the box before it were issued at all!

I : What that means?

S: The oil issued 50\% and expelled again one-third of the rest

I : Is that the expression $50 \%+1 / 3$ correct for the amount of oil issued from its box?

S: Yes, that's correct.

I : Are you sure?

S: Sure, Because the problem asked the amount of oil before it expelled from the box!

I : Why you did not write in the reason box your reason based on the information on the problem?

$\mathrm{S}$ : Because I confused about the reason, because the teacher never practice this kind of question to us (Students)!
Based on the results of that interview can be seen that the students were able to express information of the problem. However, this student is made a mistake in mentioning the exact mathematical models to the information known about. Students do not write all information that he known about the problem on the answer sheet. That happens because he did not use to practice this kind of question (yes/no question with the reason).

Here is one example of student' answer on problem number 2 .

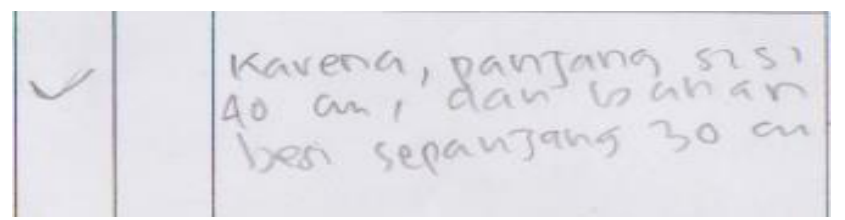

Fig. 4 Student's Answer of Problem 2

Figure 4 shows that the student tick the column right and write his reason in the reason box. He writes "because the length $40 \mathrm{~cm}$, and the material has $30 \mathrm{~m}$ long". This student only write what is known from the problems but he did not make what is asked from the problem. Therefore we conducted interview with him. Here is the transcript of the interviewer (I) with the student (S).

I : Please read that problem (Problem 2)!

S: (Reading problem 2)

I : Do you understand that problem?

S: Yes, I am

I : What information that you get from that problem?

$\mathrm{S}$ : Mr Budi want to make a cube chicken coop with the frame made of iron.

I : What do you know from the problem?

$\mathrm{S}$ : The length is 40 centimeters and the material has 30 meters long.

I : Is that the only information that you get from the problem?

S: Yes.

I : Is that the question of the problem also give us information?

S: (Think for a while) mmmm, no.

I : Are you sure?

S: Yes, I am, that my understanding.

Based on that transcript, we see that student only understand that the information from only what is known from the problem. He thinks that the question not giving any information in order to get the correct answe. This means that student get an error in understanding the problem. He did not able to retell and rewrite what is known and asked from the problem.

Another student answer on problem number 2 with different reason as shown in figure 5 below. 


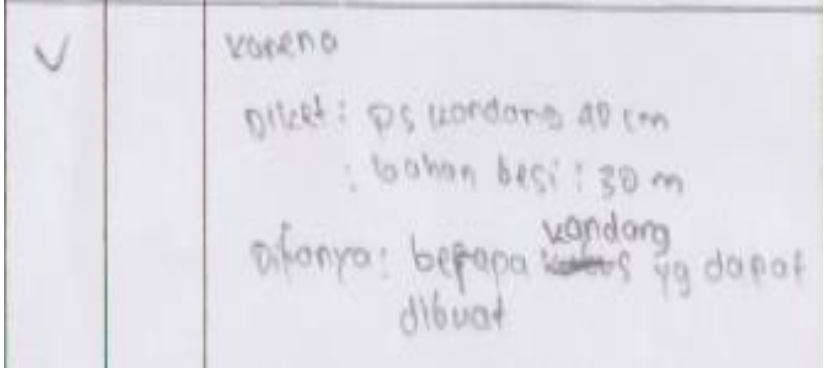

Fig. 5 Another Answer of Problem Number 2

Figure 5 shows that the student tick the column right and write his reason in the reason box. He writes what is known and asked from the problem. This student make an error in ticking given column but stated all the information about the problem on the reason. Therefore we conducted interview with him. Here is the transcript of the interviewer (I) with the student $(\mathrm{S})$.

I : Please read that problem (Problem 2)!

S: (Reading problem 2)

I : Do you understand that problem?

S: Yes, I am

I : What information that you get from that problem?

$\mathrm{S}$ : The length of the cage is 40 centimeters and the material that Mr. Budi has 30 meters long.

I : What do you know from the problem?

$\mathrm{S}$ : The length 40 centimeters and the material 30 meters.

$\mathrm{I}$ : Is that the only information that you get from the problem?

S: Yes.

I : Is that the question of the problem also give us information?

S: Yes.

I : If like that, so the information that we can get from the problem is what is known and asked from the problem?

S: Yes.

I : So, why do you give your tick on the right column?

S: Sorry, that is my fault.

Based on the transcript, we can see that the student know about information on the problem, he know about what the question asked. However, he makes an error on determining the statement right or wrong. That happened because he did not answer the problem carefully.

In conclusion, most of the students are able to understand the given problem, but there are some mistakes made by the students. Some students does not write the information about what are known and asked about the problem. Some students just write down what are known or are asked only. There are also students who copy the problem and did not make known and asked in the mathematics statements.

\section{CONSLUSION AND RECOMMENDATION}

In general, students made mistakes in understanding the problem of what is known and what is asked. It caused by the ability of students to understand mathematical sentence is low. Another factor that causes an error in understanding the problem is unfamiliarity of students to practice in order to improve their understanding about mathematical sentences. They tend to be taught about the procedure in solving a mathematical problem without understanding the insight of the procedure.

In addition, the opportunity to practice, to argue and to express the situation in mathematical sentences by the students needs to be done. The exercise may be through class discussion by giving them chance to create a mathematical sentence by providing contextual problem, so that students are accustomed to make a mathematical model of situation. For that, students need more time and opportunity to express their ideas or their understanding of mathematical phenomena. Teachers are not the central of learning but it was students who became central to learning, which is known as students centered. Teachers have a very important role to build students' understanding in order to avoid misconceptions or lack of understanding on a mathematical formula which in line with [7].

\section{REFERENCES}

[1] Arikunto. Suharsimi, Dasar-dasar Evaluasi Pendidikan, Jakarta. Bumi Aksara, 2005.

[2] Fauzan. Ahmad, Applying Realistic Mathematics Education (RME) in Teaching Geometry in Indonesian Primary School, Thesis University of Twente, 2002.

[3] Fridgo Tasman, Isra N, Yenti. S. H, "Analisis kesalahan transformasi soal pada kemampuan representasi matematis secara simbolik", Eksakta, vol. 2(Juli 2016), pp. 24-30, 2016.

[4] Hudiono, Representasi Dalam Pembelajaran Matematika", Pontianak: STAIN Pontianak Press, 2007.

[5] Permendiknas no 22 tahun 2006, Tentang Standar Proses Pendidikan Dasar dan Menengah.

[6] Sukardi, Metodologi Penelitian Pendidikan Kompetensi Dan Praktiknya, Jakarta: Bumi Aksara, 2009.

[7] Tasman. F, \& Ahmad. D, "Visualizing Volume to Help Students Understand the Disk Method on Calculus Integral Course", IOP Conference Series: Materials Science and Engineering, 335, 012112. https://doi.org/10.1088/1757-899X/335/1/012112, 2018.

[8] Tasman. F., den Hertog. J., \& Hartono. Y, "Helping students acquainted with multiplication in rectangular model", IndoMS J.M.E, vol. 2, pp. 185-198, 2011.

[9] Wijaya. Ariyadi, "Kesalahan Siswa Dalam Memilah Data Relevan Pada Soal Matematika Berbasis Konteks, Yogyakarta”, Jurnal pendidikan ISBN: $978.602 .361 .002 .0 \quad$ tersedia di http://jurdik.matematika.uny.com, 2015. 